\title{
ФОРМУВАННЯ КЛАСИФІКАЦІЙНИХ ПІДХОДІВ ДО ВИЗНАЧЕННЯ СУТНОСТІ ФІНАНОСОВОЇ БЕЗПЕКИ ПІДПРИЄМСТВА В СУЧАСНИХ ЕКОНОМІЧНИХ УМОВАХ
}

\begin{abstract}
Проведено аналіз тлумачення поняття «фінансова безпека підприємства». Контекстуальний аналіз було проведено за наступними структурними елементами: серцевина визначення; позиція, з якої підходять до трактування; спрямованість поняття; особливості впливу. За результатами проведеного контекстуального аналізу тлумачення поняття "фінансова безпека підприємства» було сформовано класифікаційні підходи до визначення поняття «фінансова безпека підприємства», які включають чотирнадиять найменувань з яких десять запропоновані автором.
\end{abstract}

Ключові слова: фінансова безпека, підприємство, фінансова безпека підприємства.

Постановка проблеми. Поняття «фінансова безпека» на сьогоднішній день можна поставити практично в один ряд 3 таким поняттям як «економічна безпека» в обсягах досліджень. Навіть коли науковці беруться досліджувати лише систему забезпечення економічної безпеки підприємства, так чи інакше торкаються i поняття «фінансова безпека». В сьогоднішніх економічних умовах дослідження поняття «фінансова безпека підприємства» набуває ще більшої актуальності через утворену політикоекономічну нестабільність в Україні, яка призвела до нових загроз, і потребує по-новому розглянути дане поняття.

Аналіз останніх досліджень і публікацій. Питанню дослідження сутності поняття «фінансова безпека підприємства» присвячено велика кількість наукових праць, в тому числі і вітчизняних, серед яких слід виділити наступні: Малик О.В. [1] (провела ретельне дослідження еволюції наукових поглядів щодо сутності фінансової безпеки підприємства); Картузов С.П. [2] (сформував основні категорії, які необхідно відносити до понятійного апарату фінансової безпеки підприємства); Араф'єва О.В., Кузенко Т.Б. [3] (розглядали фінансову безпеку з позиції шести підходів); Мандзіновська Х.О.,. Штангрет А.М, Котляревський Я.В., Мельников О.В. [4] (сформували декомпозицію трактування поняття «фінансова безпека підприємства») та ін.

Попри науковий доробок вказаних дослідників слід наголосити, що на сьогоднішній день не проведено належного контекстуального аналізу визначення сутності поняття «фінансова безпека підприємства».

(C) Силкін Олександр Сергійович, аспірант, Українська академія друкарства, м. Львів, тел.: 0964441055, email: drvel@ukr.net
Формулювання цілей статті. Метою статті $\epsilon$ проведення контекстуального аналізу, та за його результатами сформувати класифікаційні підходи до визначення поняття «фінансова безпека підприємства».

Опис основного матеріалу дослідження. Поняття «фінансова безпека» утворилось внаслідок вивчення поняття «економічна безпека», коли науковці-економісти усвідомили, наскільки важливу роль відіграє фінансова діяльність в системі забезпечення економічної безпеки підприємства.

На законодавчому рівні визначення поняття «фінансова безпека підприємства» немає, але варто відмітити, що існує проект Концепції фінансової безпеки України [5], де фінансову безпеку відносять до частини економічної безпеки, яка відображає стан захищеності ключових інтересів громадянина, підприємства, регіону та держави у фінансовій сфері від негативного впливу ряду загроз.

Провівши аналіз трактування поняття «фінансова безпека підприємства», ми дослідили визначення, яке подають автори i розбили їх на декілька ключових деталей, які відсортували, 3 метою встановлення відмінностей між ними та визначення формату розгляду даної категорії (табл.1).

Контекстуальний аналіз передбачає виділення наступних структурних елементів поняття «фінансова безпека підприємства»:

- серцевина визначення;

- позиція, з якої підходять до трактування;

- спрямованість поняття;

- особливості впливу.

Як видно 3 проведенного контекстуального аналізу, зображеного в табл.1, серцевиною визначення «фінансова безпека підприємства» $\epsilon$ наступні поняття: стан, захист, рівень, складова, здатність, сукупність, вид, процес та міра. 
Таблиця 1

Контекстуальний аналіз поняття «фінансова безпека підприсмства»*

\begin{tabular}{|c|c|c|c|c|}
\hline $\begin{array}{l}\text { Серцевина } \\
\text { визначення }\end{array}$ & $\begin{array}{l}\text { Позиція, } 3 \text { якої } \\
\text { підходять до } \\
\text { трактування }\end{array}$ & $\begin{array}{c}\text { Спрямованість } \\
\text { поняття }\end{array}$ & $\begin{array}{l}\text { Особливості } \\
\text { впливу }\end{array}$ & Автори \\
\hline \multirow{8}{*}{ Стан } & \multirow[b]{2}{*}{ підприємства } & $\begin{array}{c}\text { на збалансування сукупності } \\
\text { фінансових інструментів та } \\
\text { технологій } \\
\end{array}$ & $\begin{array}{c}\text { формування стійкості до } \\
\text { внутрішніх і зовнішніх } \\
\text { загроз }\end{array}$ & $\begin{array}{l}\text { Ортинський В., } \\
\text { Керницький I., } \\
\text { Живко 3.Б. [6] }\end{array}$ \\
\hline & & $\begin{array}{c}\text { на забезпечення фінансової } \\
\text { стійкості, платоспроможності } \\
\text { та ліквідності на довгострокову } \\
\text { перспективу } \\
\end{array}$ & \multirow{2}{*}{$\begin{array}{c}\text { протидіяти загрозам } \\
\text { зовнішнього та } \\
\text { внутрішнього середовища }\end{array}$} & $\begin{array}{c}\text { Мандзіновська Х., } \\
\text { Штангрет А., } \\
\text { Котляревський Я., О. } \\
\text { Мельников [4] }\end{array}$ \\
\hline & $\begin{array}{c}\text { фінансової } \\
\text { стабільності }\end{array}$ & на реалізацію стратегії & & Папехін Р. [7] \\
\hline & $\begin{array}{l}\text { використання } \\
\text { показників }\end{array}$ & на отримання інформації & $\begin{array}{c}\text { досягнення певного рівня } \\
\text { показників }\end{array}$ & Кузенко Т. [8] \\
\hline & $\begin{array}{l}\text { використання } \\
\text { ресурсів }\end{array}$ & $\begin{array}{c}\text { для утворення синтетичного } \\
\text { індикатора поточного } \\
\text { фінансово-господарського } \\
\text { стану } \\
\end{array}$ & $\begin{array}{c}\text { забезпечення } \\
\text { технологічного та } \\
\text { фінансового розвитку }\end{array}$ & $\begin{array}{l}\text { Донець, } \\
\text { Ващенко Н.В.[9], } \\
\text { Мунтіян B.I. [10] }\end{array}$ \\
\hline & \multirow{3}{*}{$\begin{array}{c}\text { який } \\
\text { характеризу- } \\
\text { ється }\end{array}$} & $\begin{array}{l}\text { забезпечення реалізації } \\
\text { фінансових інтересів }\end{array}$ & $\begin{array}{c}\text { формування стійкості до } \\
\text { внутрішніх і зовнішніх } \\
\text { загроз } \\
\end{array}$ & Горячева К.С.[11] \\
\hline & & \multirow{3}{*}{$\begin{array}{c}\text { на стабільну захищеність } \\
\text { фінансових інтересів }\end{array}$} & $\begin{array}{c}\text { від ідентифікованих } \\
\text { ендогенних і екзогенних } \\
\text { загроз } \\
\end{array}$ & Могиліна Л. [12] \\
\hline & & & $\begin{array}{c}\text { вчасне реагування на } \\
\text { небезпеки і загрози } \\
\text { зовнішнього й } \\
\text { внутрішнього характеру }\end{array}$ & Малик О.В. [1] \\
\hline \multirow[b]{2}{*}{ рівень } & $\begin{array}{c}\text { фінансового } \\
\text { стану } \\
\end{array}$ & & $\begin{array}{c}\text { від реальних і } \\
\text { потенційних загроз }\end{array}$ & Бланк I. [13] \\
\hline & захищеності & \multirow{2}{*}{$\begin{array}{c}\text { на забезпечення фінансовими } \\
\text { ресурсами }\end{array}$} & $\begin{array}{c}\text { достатній для задоволення } \\
\text { потреб і виконання } \\
\text { забов'язань }\end{array}$ & Барановський О. [14] \\
\hline \multirow{3}{*}{ складова } & \multirow{3}{*}{$\begin{array}{l}\text { економічної } \\
\text { безпеки }\end{array}$} & & $\begin{array}{l}\text { достатній рівень } \\
\text { ліквідності активів }\end{array}$ & Судакова О. [15] \\
\hline & & \multicolumn{2}{|c|}{ ефективне використання корпоративних ресурсів } & Покропивний С. [16] \\
\hline & & $\begin{array}{c}\text { на забезпечення оптимального } \\
\text { залучення і використання } \\
\text { фінансових ресурсів }\end{array}$ & $\begin{array}{c}\text { спроможність } \\
\text { ідентифікувати небезпеки } \\
\text { та загрози стану } \\
\text { підприємства } \\
\end{array}$ & $\begin{array}{l}\text { Погосова М., } \\
\text { Лебедєва В. [17] }\end{array}$ \\
\hline здатність & $\begin{array}{l}\text { самостійно } \\
\text { розробляти }\end{array}$ & $\begin{array}{c}\text { на проведення фінансової } \\
\text { стратегії }\end{array}$ & $\begin{array}{c}\text { в умовах невизначеного і } \\
\text { конкурентного } \\
\text { середовища }\end{array}$ & $\begin{array}{l}\text { Кракос Ю., } \\
\text { Разгон Р.[18] }\end{array}$ \\
\hline вид & $\begin{array}{l}\text { економічних } \\
\text { відносин }\end{array}$ & $\begin{array}{c}\text { на забезпечення оптимального } \\
\text { фінансового стану }\end{array}$ & $\begin{array}{c}\text { протистояти зовнішнім і } \\
\text { внутрішнім загрозам }\end{array}$ & Сорокіна О. [19] \\
\hline процес & забезпечення & $\begin{array}{c}\text { на формування фінансової } \\
\text { рівноваги в поточній і } \\
\text { стратегічній перспективі }\end{array}$ & $\begin{array}{c}\text { негативного впливу } \\
\text { зовнішніх і внутрішніх } \\
\text { фінансових загроз } \\
\end{array}$ & $\begin{array}{c}\text { Пройда-Носик Н. } \\
{[20]}\end{array}$ \\
\hline діяльність & $\begin{array}{l}\text { з управління } \\
\text { ризиками }\end{array}$ & $\begin{array}{c}\text { на забезпечення захисту } \\
\text { інтересів підприємства }\end{array}$ & $\begin{array}{c}\text { від зовнішніх і внутрішніх } \\
\text { загроз }\end{array}$ & $\begin{array}{l}\text { Кириченко О., } \\
\text { Кудря I. [21] }\end{array}$ \\
\hline \multirow{3}{*}{ сукупність } & чинників & $\begin{array}{c}\text { на забезпечення незалежності, } \\
\text { стійкості, здатності до } \\
\text { прогресу }\end{array}$ & $\begin{array}{c}\text { в умовах дестабілізуючих } \\
\text { факторів }\end{array}$ & Капустін Н. [22] \\
\hline & \multirow{2}{*}{ заходів } & на запобігання збиткам & $\begin{array}{c}\text { в умовах негативного } \\
\text { впливу чинників }\end{array}$ & $\begin{array}{c}\text { Голухов Г., } \\
\text { Шиленко Ю. [23] }\end{array}$ \\
\hline & & $\begin{array}{c}\text { на підвищення фінансової } \\
\text { стійкості }\end{array}$ & $\begin{array}{l}\text { від впливу негативних } \\
\text { ринкових процесів }\end{array}$ & Раздіна Є. [24] \\
\hline \multirow[b]{2}{*}{ захист } & $\begin{array}{l}\text { від фінансових } \\
\text { втрат } \\
\end{array}$ & $\begin{array}{l}\text { ефективне використання } \\
\text { корпоративних ресурсів }\end{array}$ & $\begin{array}{c}\text { попередження } \\
\text { банкрутства }\end{array}$ & Реверчук Н. [25] \\
\hline & потенціалу & $\begin{array}{c}\text { на захищеність науково- } \\
\text { технічного, виробничого та } \\
\text { кадрового потенціалу }\end{array}$ & $\begin{array}{c}\text { від прямих або непрямих } \\
\text { загроз }\end{array}$ & Бендиков М. [26] \\
\hline
\end{tabular}




\begin{tabular}{|c|c|c|c|c|}
\hline & \multicolumn{4}{|c|}{ Продовжсення табл. 1} \\
\hline & $\begin{array}{l}\text { фінансових } \\
\text { ресурсів }\end{array}$ & $\begin{array}{c}\text { на забезпечення домашніх } \\
\text { господарств, підприємств, } \\
\text { організацій та установ } \\
\text { фінансовими ресурсами } \\
\end{array}$ & $\begin{array}{c}\text { достатній для } \\
\text { задоволення потреб і } \\
\text { виконання забов'язань }\end{array}$ & $\begin{array}{l}\text { Загородній А., } \\
\text { Вознюк Г. [27] }\end{array}$ \\
\hline & $\begin{array}{c}\text { фінасово- } \\
\text { економічних } \\
\text { інтересів }\end{array}$ & $\begin{array}{c}\text { на створення фінансово- } \\
\text { економічних передумов для } \\
\text { стійкого розвитку на } \\
\text { поточному та довгостроковому } \\
\text { періодах } \\
\end{array}$ & $\begin{array}{l}\text { від внутрішніх і } \\
\text { зовнішніх загроз }\end{array}$ & $\begin{array}{l}\text { Мойсеєнко I., } \\
\text { Марченко О. [28] }\end{array}$ \\
\hline мipa & гармонізації & \multicolumn{2}{|c|}{$\begin{array}{l}\text { гармонія в часі і просторі інтересів пов’язаними з } \\
\text { підприємством суб'єктів зовнішнього середовища }\end{array}$} & $\begin{array}{c}\text { Козаченко Г., } \\
\text { Пономарьов В., } \\
\text { Ляшенко О. [29] }\end{array}$ \\
\hline
\end{tabular}

*Сформовано автором

Окрім цього, кожний науковець бачить продовження даного поняття по-своєму: наприклад як захист, але саме від фінансових втрат [25]; як захист, але потенціалу [26]; як захист фінансових ресурсів [27] і т.д.

Така велика кількість тлумачень поняття «фінансова безпека підприємства» свідчить про те, що сьогодні немає єдиного підходу щодо його визначення, i тому було сформовано класифікаційні підходи щодо визначення даного поняття [1,c.21], які, на нашу думку, варто розширити та удосконалити (табл.2).

Завдяки проведеному контекстуальному аналізу тлумачення поняття «фінансова безпека підприємства» можна максимально повно розкрити зміст даного поняття та розширити існуючі класифікаційні підходи у залежності від серцевини визначення, позиції з якої підходять до трактування, спрямованості та особливості впливу.

Варто наголосити, що застосування класифікаційного методу щодо тлумачення поняття «фінансова безпека підприємства» стимулює науковий розвиток даного поняття $\mathrm{i}$ всієї економічної науки в цілому, оскільки виводить накопичені знання щодо того чи іншого поняття на рівень теоретичних суджень i закономірностей.

Таблиця 2

Класифікація підходів до визначення поняття «фінансова безпека підприємства» *

\begin{tabular}{|c|c|}
\hline Ступеневий підхід & як необхідний ступінь (рівень) фінансового стану \\
\hline Сукупний підхід & $\begin{array}{l}\text { як сукупність заходів або чинників, які призначені для забезпечення належного } \\
\text { рівня фінансових показників }\end{array}$ \\
\hline Предметний підхід & як стан певного об’єкту (підприємства) \\
\hline Захисний підхід & як захист фінансових інтересів підприємства \\
\hline Ризиковий підхід & як діяльність з управління фінансовими ризиками \\
\hline $\begin{array}{l}\text { Ресурсно- } \\
\text { функціональний підхід }\end{array}$ & як стан ефективного використання ресурсів \\
\hline Різновидний підхід & як певний вид економічних відносин \\
\hline \multicolumn{2}{|r|}{ За позицієо, з якої підходять до трактування } \\
\hline Злагоджений підхід & $\begin{array}{l}\text { як міра гармонізації інтересів з інтересами інших суб’єктів господарювання, які } \\
\text { пов'язані з підприємством }\end{array}$ \\
\hline Складовий підхід & як частина економічної безпеки підприємства \\
\hline Стратегічний підхід & Як спроможність самостійн розробляти та реалізовувати фінансову стратегін \\
\hline \multicolumn{2}{|r|}{ За спрямованісто тлумачення } \\
\hline Тривалісний підхід & $\begin{array}{l}\begin{array}{l}\text { фiнансова безпека } \\
\text { періоди }\end{array} \\
\end{array}$ \\
\hline Стійкісний підхід & як забезпечення рівноваги, стійкості, збалансованості \\
\hline Корпоративний підхід & як ефективне використання корпоративних ресурсів \\
\hline \multicolumn{2}{|r|}{ За особливістю впливу } \\
\hline $\begin{array}{l}\text { Попереджувальний } \\
\text { підхід }\end{array}$ & $\begin{array}{l}\text { як спроможність раннього попередження банкрутства та своєчасної ідентифікації } \\
\text { небезпек і загроз }\end{array}$ \\
\hline
\end{tabular}

* Систематизовано та складено автором (авторські позиції виділено) 
Висновки і перспективи подальших досліджень. Запропонований класифікаційний підхід дозволяе розширити розуміння досліджуваного поняття «фінансова безпека підприємства» i сформувати своє бачення даного поняття, базуючись і враховуючі усі особливості кожного 3 підходів. Так, на нашу думку, фінансову безпеку підприємства слід розуміти як такий фінансовий стан підприємства, який дозволяє забезпечити належний рівень фінансової стійкості, необхідний для підтримки високої захищеності фінансових інтересів, 3 метою комфортного функціонування в умовах негативного впливу внутрішніх і зовнішніх загроз.

В подальшому, слід приділити увагу удосконаленню механізму забезпечення фінансової безпеки підприємства.

\section{ПЕРЕЛІК ВИКОРИСТАНИХ ДЖЕРЕЛ}

1. Малик О.В. Формування механізму управління фінансовою безпекою підприємства / О.В. Малик // Дисертація на здобуття наукового ступеня к.е.н. - Хмельницький. - 2015. - 263 с.

2. Картузов Є.П. Визначення фінансової безпеки підприємства:поняття, зміст, значення і функціональні аспекти / С.П. Картузов // Економіка та управління підприємствами. Актуальні проблеми економіки №8 (134). 2012. - C.172-181.

3. Ареф'єва О.В. Економічні основи формування фінансової складової економічної безпеки / О.В. Ареф’єва, Т.Б. Кузенко // Актуальні проблеми економіки. - 2009. - №1 - С.98-103.

4. Фінансова безпека машинобудівного підприємства : Методичні засади формування та забезпечення : моногр. / Х. О. Мандзіновська, А. М. Штангрет, Я. В. Котляревський, О. В. Мельников ;за заг. ред. А. М. Штангрета. - Львів : Укр. акад. друкарства, 2016. - 226 с.

5. Проект «Концепція фінансової безпеки України». Розробники: д.е.н. Барановський О.І., кандидати економічних наук Блащук Ю.О., Пузяк М.І., Новошинська Л.В., Резнікова О.О., Романченко О.В., Стасюк Ф.Ф., Фещенко В.В. [Електронний ресурс] - Режим доступу : www.ufin.com.ua

6. Економічна безпека підприємств, організацій та установ : навч. посіб. / [В. Л. Ортинський, І. С. Керницький, 3. Б. Живко та ін. ]. - К. : Правова єдність,2009. - 544 с.

7. Петренко Л. М. Моделювання процесів управління фінансовою безпекою підприємства : автореф. дис. канд. екон. наук : 08.00.11 / Л. М. Петренко ; [Київ. нац. екон. ун-т ім. Вадима Гетьмана. — К., 2010. — 19 с.

8. Кузенко Т. Б. Управление финансовой безопасностью на предприятии / Т. Б. Кузенко, В. В. Прохорова, Н. В. Саблина // Бизнес Информ. - 2007. - №12 (1). - С. 27-29.

9. Донець Л. І. Економічна безпека підприємства / Л. І. Донець,Н. В. Ващенко. - К. : Центр учбової літератури, 2008. - 240 с.

10. Мунтіян В. І. Економічна безпека України / В. І. Мунтіян. - К. :КВІЦ, 1999.- 464 с.

11. Горячева К. С. Механізм управління фінансовою безпекою підприємства : дис. ... канд. екон. наук: 08.06.01 / К. С. Горячева; Київський національний університет технологій та дизайну. - К., 2006. - 174 с.

12. Могиліна Л. А. Управління фінансовою безпекою підприємств в умовах економічної нестабільності : автореф. дис. ... канд. екон. наук: 08.00.08 /Л. А. Могиліна. - Суми, 2015. - 24 с.

13. Бланк И. А. Управление финансовой безопасностью предприятия / И. А. Бланк. - К. : Эльга, Ника-Центр, 2004. - $784 \mathrm{c}$.

14. Барановський О. І. Фінансова безпека: моногр. / О. І. Барановський. - К. : Фенікс, 1999. - 338 с.

15. Судакова О. І. Стратегічне управління фінансовою безпекою підприємства / О. I. Судакова // Економічний простір. - 2008. - № 9. - С. 140-148.

16. Економіка підприємства : підруч. / [ред. С. Ф. Покропивний] - 2-е вид., перероб. і доп. - К. : КНЕУ, 2001. $-528 \mathrm{c}$.

17. Погосова М. Ю. Аналіз методичного забезпечення оцінювання фінансової безпеки підприємства [Електронний peсурс] / М. Ю. Погосова, В. С.Лебедєва // Экономические науки. - Режим доступу : http://www.rusnauka.com.

18. Кракос Ю. Подход к оценке уровня финансовой составляющей экономической безопасности предприятия / Ю. Кракос, Н. Серик // Экономика. Финансы. Право. - 2006. - № 12. - С. 7-12.

19. Сорокіна О. М. Зміст дефініції «фінансова безпека» / О. М. Сорокіна // Торгівля і ринок України. - 2009. - Вип. 28, Т. 3. - С. 270-274.

20. Пойда-Носик Н. Н. Сутність фінансової безпеки суб'єктів підприємництва та ії роль в забезпеченні національної економічної безпеки / Н. Н.Пройда-Носик // Вісн. ЖДТУ. - 2011. - № 1 (55). - С. 340-342.

21. Кириленко В. І. Інвестиційна складова економічної безпеки : моногр. / В. І. Кириленко. - К.: КНЕУ, 2005. -232 c.

22. Капустин Н. Экономическая безопасность отрасли и фирмы / Н. Капустін // Бизнес-информ. - 1999. № 11-12. - С. 45-47.

23.Гринюк Н. А. Методичні підходи до обгрунтування індикаторів оцінки рівня фінансової безпеки підприємництва / Н. А. Гринюк // Проблеми науки. -2008. - № 6. - С. 35-40.

24. Раздина Е. Комемерческая информация и экономическая безопасносность предприятия / Е. Раздина // Бизнес Информ. - 2007. - № 24. - С. 63-65. 
25. Реверчук Н. Й. Управління економічною безпекою підприємницьких структур / Н. Й. Реверчук. - Львів : ЛБІ НБУ, 2004. - 195 с.

26. Бендиков М. Экономическая безопасность промышленного предприятия (организационно-методический аспект) / М. Бендиков // Консультант директора. - 2009. - №2. - С. 7-13.

27. Загородній А. Г. Фінансово-економічний словник / А. Г. Загородній, Г.Л. Вознюк. - К. : Знання, 2007 $1079 \mathrm{c}$.

28. Мойсеєнко I. П. Управління фінансово-економічною безпекою підприємства / I. П. Мойсеєнко, О. М. Марченко. - Львів, 2011. - 380 с.

29. Козаченко Г. В. Економічна безпека підприємства : Сутність та механізм забезпечення : моногр. / Г. В. Козаченко, В. П. Пономарьов, О. М. Ляшенко.- К. : Лібра, 2003. - 250 с.

\section{REFERENCES}

1. Maly`k O.V. (2015) Formuvannya mexanizmu upravlinnya finansovoyu bezpekoyu pidpry`yemstva [Formation of the financial management mechanism of the enterprise] / Dy`sertaciya na zdobuttya naukovogo stupenya k.e.n. Xmel`ny`cz`ky`j. [in Ukrainian].

2. Kartuzov Y.P. (2012) Vy`znachennya finansovoyi bezpeky` pidpry`yemstva:ponyattya, zmist, znachennya i funkcional'ni aspekty' [Definition of financial security of the enterprise: concept, content, meaning and functional aspects] / Ekonomika ta upravlinnya pidpry`yemstvamy`. Aktual`ni problemy` ekonomiky`\#8 (134). [in Ukrainian].

3. Aref'yeva O.V. Kuzenko T.B. (2009) Ekonomichni osnovy formuvannya finansovoyi skladovoyi ekonomichnoyi bezpeky` [Economic basis for the formation of financial economic security] / Aktual`ni problemy` ekonomiky`. [in Ukrainian].

4. Mandzinovs`ka X. O., Shtangret A. M., Kotlyarevs`ky`j Y. V., Mel`ny`kov O. V. (2016) Finansova bezpeka mashy`nobudivnogo pidpry`yemstva : Metody`chni zasady` formuvannya ta zabezpechennya [Financial security of the machine-building enterprise: Methodological foundations of formation and provision] : monogr. - L`viv : Ukr. akad. Drukarstva [in Ukrainian].

5. Baranovs`ky`j O.I., Blashhuk Y.O., Puzyak M.I., Novoshy`ns`ka L.V., Reznikova O.O., Romanchenko O.V., Stasyuk F.F., Feshhenko V.V. Proekt «Koncepciya finansovoyi bezpeky` Ukrayiny`» [The project “The concept of financial security of Ukraine"]. [Elektronny`j resurs] - Rezhy`m dostupu : www.ufin.com.ua [in Ukrainian].

6. V. L. Orty`ns`ky`j V. L., Kerny`cz`ky`j I. S., Zhy`vko Z. B. (2009) Ekonomichna bezpeka pidpry`yemstv, organizacij ta ustanov : navch. posib. [Economic security of enterprises, organizations and institutions] / - K. : Pravova yednist' [in Ukrainian].

7. Petrenko L. M. (2010) Modelyuvannya procesiv upravlinnya finansovoyu bezpekoyu pidpry`yemstva : avtoref. dy`s. kand. ekon. nauk : 08.00.11 [Modeling of financial management processes of the enterprise] / [Ky`yiv. nacz. ekon. un-t im. Vady`ma Get`mana. [in Ukrainian].

8. Kuzenko T. B. Proxorova V. V., Sably`na N. V. (2007) Upravleny`e fy`nansovoj bezopasnost yu na predpry`yaty`y` [Management of financial security in the enterprise] / By`znes Y`nform. [in Ukrainian].

9. Donecz L. I., Vashhenko N.V. (2008) Ekonomichna bezpeka pidpry`yemstva [Economic security of the enterprise] / - K. : Centr uchbovoyi literatury` [in Ukrainian].

10. Muntiyan V. I. (1999) Ekonomichna bezpeka Ukrayiny` [Economic security of Ukraine] . - K. :KVICz [in Ukrainian].

11. Goryacheva K. S. (2006) Mexanizm upravlinnya finansovoyu bezpekoyu pidpry`yemstva [The mechanism of financial security management of the enterprise] / Ky`yivs`ky`j nacional`ny`j universy`tet texnologij ta dy`zajnu. [in Ukrainian].

12. Mogy`lina L. A. (2015) Upravlinnya finansovoyu bezpekoyu pidpry`yemstv v umovax ekonomichnoyi nestabil nosti [Management of the financial security of enterprises in the conditions of economic instability] - Sumy` [in Ukrainian].

13. Blank Y`. A. (2004) Upravleny`e fy`nansovoj bezopasnost yu predpry`yaty`ya [Financial management of the enterprise] - K. : Эl`ga, Ny`ka-Centr [in Ukrainian].

14. Baranovs`ky`j O. I. (1999) Finansova bezpeka: monogr. [Financial security]- K. : Feniks [in Ukrainian].

15. Sudakova O. I. (2008) Strategichne upravlinnya finansovoyu bezpekoyu pidpry`yemstva [Strategic management of financial security of the enterprise] / Ekonomichny`j prostir. [in Ukrainian].

16. Pokropy`vny`j S.F. (2001) Ekonomika pidpry`yemstva) [Business Economics] - 2-e vy`d., pererob. i dop. - K. : KNEU [in Ukrainian].

17. Pogosova M. Y. Lebedyeva M.Y. Analiz metody`chnogo zabezpechennya ocinyuvannya finansovoyi bezpeky` pidpry`yemstva [Analysis of methodological support for assessing the financial security of an enterprise] / Эkonomy`chesky`e nauky`. [in Ukrainian].

18. Krakos Y. Sery`k N. (2006) Podxod k ocenke urovnya fy`nansovoj sostavlyayushhej эkonomy`cheskoj bezopasnosty` predpry`yaty`ya [Approach to assessing the level of the financial component of the economic security of the enterprise] / Ekonomika. Finansy`. Pravo. [in Ukrainian].

19. Sorokina O. M. (2009) Zmist definiciyi «finansova bezpeka» [Content of the definition of "financial security"] / Torgivlya i ry`nok Ukrayiny`. [in Ukrainian]. 
20. Pojda-Nosy`k N. N. (2011) Sutnist` finansovoyi bezpeky` sub'yektiv pidpry`yemny`cztva ta yiyi rol` v zabezpechenni nacional'noyi ekonomichnoyi bezpeky` [Essence of financial security of business entities and its role in ensuring national economic security] / Visn. ZhDTU. [in Ukrainian].

21. Ky`ry`lenko V. I. (2005) Investy `cijna skladova ekonomichnoyi bezpeky` : monogr. [Investment component of economic security] [in Ukrainian].

22. Kapustin N. (1999) Эkonomy 'cheskaya bezopasnost` otrasly`y` fy`rmu [Economic security of the industry and firms] / By`znes-y`nform. [in Ukrainian].

23. Gry`nyuk N. A. (2008) Metody`chni pidxody` do obg`runtuvannya indy`katoriv ocinky` rivnya finansovoyi bezpeky' pidpry`yemny'cztva [Methodological approaches to the justification of indicators for assessing the level of financial security of entrepreneurship] / Problemy` nauky`. [in Ukrainian].

24. Razdina E. (2007) Komemercheskaya y'nformacy'ya y’ эkonomy ‘cheskaya bezopasnosnost’ predpry`yaty'ya [Kememerskoe information and economic security of the enterprise] / By’znes Y`nform. [in Ukrainian].

25. Reverchuk N. J. (2004) Upravlinnya ekonomichnoyu bezpekoyu pidpry`yemny`cz ky`x struktur [Management of economic security of entrepreneurial structures] - L`viv : LBI NBU [in Ukrainian].

26. Bendy`kov M. (2009) Эkonomy'cheskaya bezopasnost` prombshlennogo predpry`yaty`ya (organy`zacy`onnometody 'chesky`j aspekt) [Economic Security of an Industrial Enterprise (Organizational and Methodological Aspect)] / Konsul`tant dy`rektora. [in Russian].

27.Zahorodniy A. H. Voznyuk A.H. (2007) Finansovo-ekonomichnyy slovnyk [Financial and Economic Dictionary] - K. : Znannya [in Ukrainian].

28. Mojseyenko I. P. Marchenko O.M. (2011) Upravlinnya finansovo-ekonomichnoyu bezpekoyu pidpry`yemstva [Management of the financial and economic security of the enterprise] - L viv[in Ukrainian].

29. Kozachenko G. V. Ponomar`ov V.P., Lyashenko O. M. (2003) Ekonomichna bezpeka pidpry`yemstva : Sutnist` ta mexanizm zabezpechennya : monogr. [Economic security of the enterprise: Essence and mechanism of provision] K. : Libra [in Ukrainian].

Одержано 12.03. 2018 p. 